\title{
Analysis of plasma IGF-I hormone level and its correlation with live weight and age in Holstein-Friesian heifers
}

\section{Summary}

The aim of this study was to evaluate the changes and relation of live weight and IGF-I plasma concentration during the rearing period in HF heifers. Number of animals was $85 \mathrm{kept}$ in similar housing and feeding conditions. Blood samples were collected monthly at the same hour of the day and weight of the calves were scaled simultaneously up to the $14^{\text {th }}$ month of age. Plasma IGF-I concentration was measured by RIA procedure. Data were analysed by STATISTICA, SPSS 10.0 version and POST HOC TEST programs. Results of this work allow to conclude that change of plasma IGF-I c.c. and live weight show similar trend. Rearing phase of calves shows three peaks: $1^{\text {st }}$ at birth; $2^{\text {nd }}$ closed to sexual maturity; $3^{\text {rd }}$ closed to first service. IGF-I-profile can be taken as similar for all individual and animals can be categorised into groups with low or high hormone concentrations. There is only negative correlation $(r=-0.24)$ between IGF-I levels at birth and at 4 months of age. Bulls have special effect on IGF-I c.c. at birth, at $5^{\text {th }}, 13^{\text {th }}$ and $14^{\text {th }}$ months of age $(\mathrm{P}<0.1)$. On contrary to previous findings IGF-I level and weight of calves correlated negatively $(\mathrm{r}=-0.31, \mathrm{P}<0.05)$ in the whole population, while within progeny groups positive and negative correlation may occur, too. Negative correlation prove the compensation ability of animals in growth rate. In comparison with the overall mean of IGF-I c.c., the subpopulation below average has lower live weight, too and with high IGF-I level a higher live weight is bound.

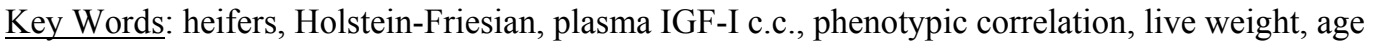

\section{Zusammenfassung}

Titel der Arbeit: Prüfung der Zusammenhänge zwischen dem Lebendgewicht, dem Alter und der IGF-I Plasmakonzentration bei Holstein-Friesian Färsen

Ziel der Untersuchungen war die Prüfung der Zusammenhänge zwischen dem Lebendgewicht und der IGF-I Plasmakonzentration während der Aufzuchtperiode bei einheitlich gehaltenen und gefütterten Holstein-Friesian Färsen. Die Blutproben wurden zur gleichen Tageszeit monatlich vom ersten bis zum 14. Lebensmonat genommen. Zum gleichen Zeitpunkt erfolgte die Wägung der Tiere. Die IGF-I Konzentration wurde mittels RIA Technik bestimmt. Die Datenverarbeitung erfolgte mit STATISTICA, SPSS, Version 10.0 und dem POT HOC TEST Programm. Die Ergebnisse zeigten eine gleiche Tendenz zwischen dem Anstieg der IGF-I Konzentration und dem Lebensalter, wobei sich bei IGF-I drei Gipfel zeigten, nämlich bei Geburt, bei der Geschlechtsreife und der Zuchtreife. Das IGF-I Profil bei Geburt kann als tierindividuell angenommen werden, so dass die Tiere in die Gruppen hohes und niedriges Niveau eingestuft werden konnten. Bis zum 4. Lebensmonat finden sich negative Korrelationen, in den Folgemonaten dagegen positive zwischen beiden Gruppen. Ein Vatereffekt auf den Hormonspiegel konnte bei Geburt und den Monaten 5, 13 und 14 nachgewiesen werden. Bei der Betrachtung der einzelnen Nachkommengruppen konnten sowohl negative als auch positive Beziehungen im Verlauf des Beobachtungszeitraumes festgestellt werden. Generell bestätigt sich der Zusammenhang zwischen dem IGF-I Niveau und der Entwicklung des Lebendgewichtes.

Schlüsselwörter: Färsen, Holstein-Friesian, IGF-I, phänotypische Korrelation, Lebendgewicht, Alter

\section{Introduction}

Selection methods used generally - excluding disturbing effects - may result in 1 percent genetic progress yearly. Beside low level of genetic merit, long generation interval detains also serving data for selection purposes. For this reason, it is necessary 
to involve genetic and physiological parameters which have immediate relations to production traits, mainly in early phase of life. The advantage of this could be realised in preselection of animals at young age.

The IGF system consists of two insulin-like growth factors (IGF-I and -II), two receptors and six binding proteins (IGFBP-1 to-6). IGFs are growth-promoting peptides, which show significant structural homology with insulin (RIDNERKNECHT and HUMBEL, 1978a, b) and also biological effects similar to those of insulin (SOARES et al., 1985).

In the experiment IGF-I (insulin-like growth factor I) originating from the group of polypeptides and showing structural homology with proinsulin was studied. IGF-I can be described by its metabolic, mitogenic and differential functions (SCHMIDT et al., 1983; GREEN et al., 1985; BASERGA et al., 1999) and it reaches the target cells by paracrin and/or autocrin effects (UNDERWOOD et al., 1986; SCHLECHTER et al., 1986). IGF-I stimulates transport of substrates, oxidation of glucose and synthesis of fat from glucose (FROESCH et al., 1986; SHAMAY et al., 1988; BAUMRUCKER et al., 1989). As growth hormone it plays fundamental role in regulation of growth intensity and protein synthesis. Having insulin like-effect, it promotes glucose to get in to cells and ensures energy for protein synthesis and growth (ZAPF et al., $1978 \mathrm{a}, \mathrm{b}$ ).

IGF-I as biochemical indicator may have relations to production traits. For this reason, a study was initiated with aim to measure its concentration during the rearing period (from birth to $14^{\text {th }}$ month of age) and the changes of it were related to the growth rate of calves.

\section{Material and methods}

For having reliable statistical evaluation the main aspect was to ensure representative number of calves concerning similar age and environment. The population consisted of 100 pure bred Holstein-Friesian calves (with a survival rate of $85 \%$ ). All investigated animals $(n=85)$ were born within a three months period to meet the above conditions. Within the population paternal-half sib groups were established. All the calves were coming from 20 bulls out of which 5 bulls had a proper progeny group for statistical analysis.

IGF-I profile of calves was studied from birth to 14 months of age. During the trial 10 $\mathrm{ml}$ blood samples were taken from the Vena jugularis monthly at the same time after feeding from each calf. Plasma IGF-I concentration was measured by RIA method in co-operation with the Molecular Biology Department of UER (Belgium) according to the procedure described by LEMAL et al. (1989).

On bases of average IGF-I concentration calculated for the entire rearing period, each individual was assorted into two groups for below (group 1) or above (group 2) the population average. At time of blood sampling weight of calves was measured, as well and general condition was scored and registered continuously during the trial. For statistical analysis SPSS $10.0^{\text {th }}$ version and STATISTICA program package were used. Beside basic statistics data were evaluated by multivariate analyses. Comparative analysis among the bulls was carried out by POST HOC TEST method. 


\section{Results}

Changes of hormone concentration can be described by determination of IGF-I plasma level form birth to $14^{\text {th }}$ month of age (Table 1). Data show that high IGF-I plasma concentration at birth $(41.1 \mathrm{mg} / \mathrm{ml})$ decreases to $23.76 \mathrm{mg} / \mathrm{ml}$ until the first month of age. After a slight increase between the $2^{\text {nd }}$ to $4^{\text {th }}$ months, IGF-I remains below the initial value which will be exceeded only at the age of 5 months $(42.87 \mathrm{mg} / \mathrm{ml})$. At age of 6 months, light decline can be observed. Plasma hormone concentration increases gradually and reaches maximum $(81.9 \mathrm{mg} / \mathrm{ml})$ at $7-11$ months of age, showing a 100 percent increase compared to the initial value at birth. IGF-I values are very similar during the last three months of the study but lower than in the $11^{\text {th }}$ month (Table 1 ). Supposed time of sexual maturity and start of breeding are marked by IGF-I peaks.

Table 1

Change of plasma IGF-I level $(\mathrm{ng} / \mathrm{ml})$ from birth until $14^{\text {th }}$ month of age $(\mathrm{n}=85)$ (Veränderung des Plasma IGF-I Niveaus (ng/ml) von Geburt bis zum 14. Lebensmonat $(\mathrm{n}=85))$

\begin{tabular}{ccccrr}
\hline Age & Mean & SD & Max. & Min. & Var. \\
\hline $\mathbf{0}$ & $\mathbf{4 1 . 1 0}$ & \pm 29.7 & 172.7 & 5.7 & 879.2 \\
$\mathbf{1}$ & 23.76 & \pm 20.3 & 115.2 & 5.2 & 410.3 \\
$\mathbf{2}$ & 35.44 & \pm 36.4 & 186.0 & 6.2 & 1322.3 \\
$\mathbf{3}$ & 32.13 & \pm 27.6 & 149.8 & 7.2 & 764.1 \\
$\mathbf{4}$ & 30.42 & \pm 20.2 & 111.0 & 7.0 & 406.7 \\
$\mathbf{5}$ & $\mathbf{4 2 . 8 7}$ & \pm 30.9 & 134.0 & 8.0 & 956.3 \\
$\mathbf{6}$ & 35.91 & \pm 26.0 & 123.0 & 7.0 & 674.8 \\
$\mathbf{7}$ & 42.67 & \pm 30.2 & 150.0 & 6.0 & 910.8 \\
$\mathbf{8}$ & 52.94 & \pm 31.5 & 152.0 & 8.0 & 992.3 \\
$\mathbf{9}$ & 62.82 & \pm 29.1 & 157.0 & 10.0 & 847.7 \\
$\mathbf{1 0}$ & 73.98 & \pm 35.7 & 160.0 & 6.0 & 1273. \\
$\mathbf{1 1}$ & $\mathbf{8 1 . 9 1}$ & \pm 32.6 & 159.0 & 21.0 & 1062.3 \\
$\mathbf{1 2}$ & 75.76 & \pm 25.6 & 142.0 & 14.0 & 654.7 \\
$\mathbf{1 3}$ & 75.98 & \pm 23.7 & 141.0 & 5.0 & 559.4 \\
$\mathbf{1 4}$ & 76.60 & \pm 27.3 & 148.0 & 15.0 & 743.2 \\
\hline
\end{tabular}

Table 2

Correlations between the averages of monthly IGF-I concentrations $(n=85)$ (Korrelationen zwischen monatlichen Durchschnittswerten der IGF-I Konzentration $(n=85))$

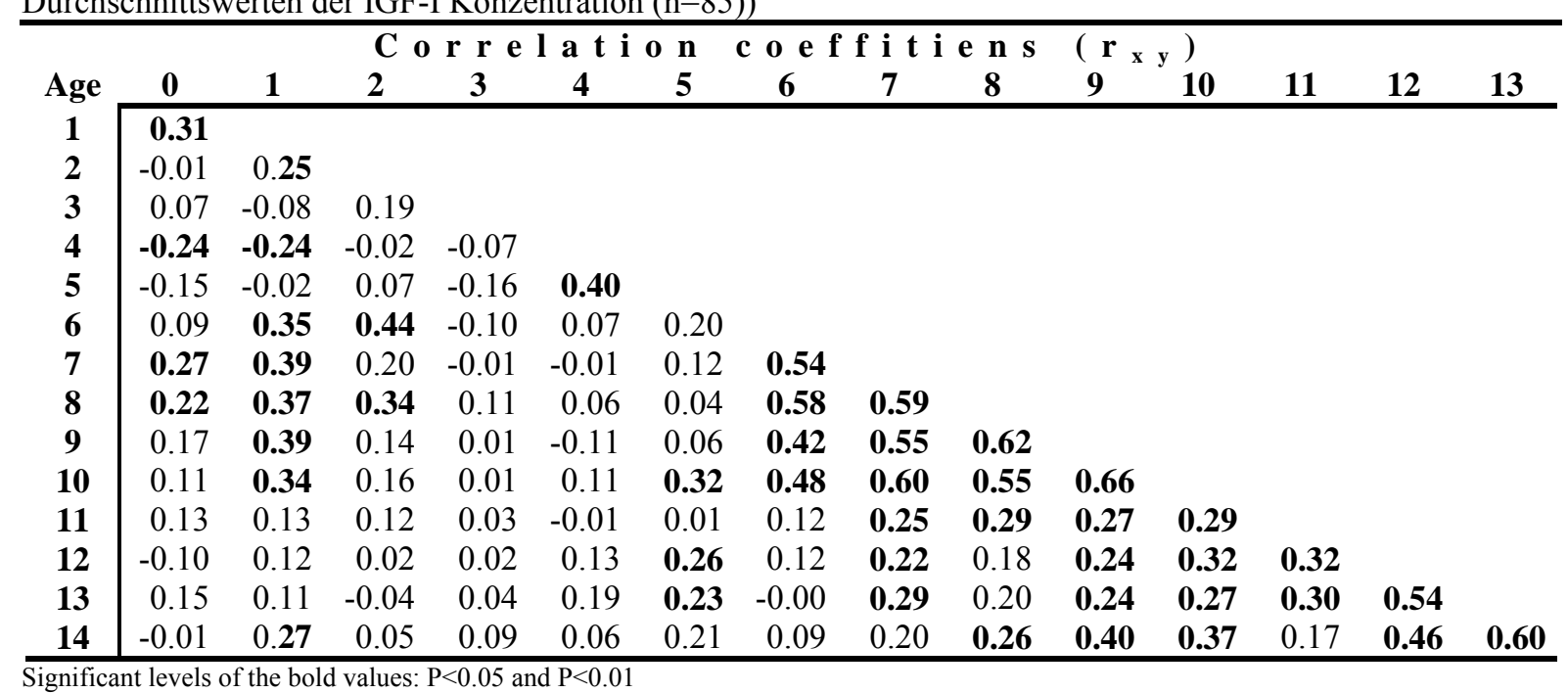

Correlations were calculated to detect ages having relation to each other. The relations were analysed by step-by-step regression method. Table 2 gives information about 
relations of monthly IGF-I averages. Significant $(\mathrm{P}>0.05$ and $\mathrm{P}<0.01)$ coefficients of correlation are marked by dark fields. IGF-I concentration at birth is in significant correlation with that of measured at first, $7^{\text {th }}$ and $8^{\text {th }}$ months of age $(\mathrm{r}=0.31 ; 0.27$ and 0.22 , respectively). On the contrary, the value at the $4^{\text {th }}$ month shows negative relationship $(\mathrm{r}=-0.34)$.

IGF-I concentration characteristic for the first month of calves has positive relations to the values of the $2^{\text {nd }} ; 6^{\text {th }}$ to $10^{\text {th }}$ and $14^{\text {th }}$ months of age, e.g. $\mathrm{r}=0.25 ; 0.33 ; 0.39 ; 0.37$; $0.39 ; 0.34$ and 0.25 , respectively. Concentration at the age of $2^{\text {nd }}$ month shows further positive correlations with values of the $6^{\text {th }}$ and $8^{\text {th }}$ months of age. The values at the $3^{\text {rd }}$ month present negative relationship $(r=-0.24)$ with value of the $4^{\text {th }}$ month. Positive correlations were registered between the $5^{\text {th }}$ and $4^{\text {th }} ; 10^{\text {th }}, 12^{\text {th }}$ and $13^{\text {th }}$ month values ( $\mathrm{r}$ $=0.40 ; 0.32,0.26$ and 0.23 , respectively).

Table 2 demonstrates that, the number and value of interrelations increases between the $6^{\text {th }}$ and $10^{\text {th }}$ month and both decrease from $11^{\text {th }}$ one. Highest positive correlation among the monthly values exists between the $9^{\text {th }}$ and $10^{\text {th }}$ month $(\mathrm{r}=-0.66)$. Middle level of regressions have been found in IGF-I concentrations among the $1^{\text {st }} ; 4^{\text {th }}, 12^{\text {th }}$ and $13^{\text {th }}$ months. The multiple correlation value is $\mathrm{R}=0.458$ with 27.02 error.

Figures in Table 1 one can suppose that IGF-I profile described for the rearing period should be characteristic for each individual but on different concentration level, due to the great standard deviation. To prove this hypothesis, IGF-I concentrations were summarised for each calf. It was established that $57 \%$ of the whole population $(n=48)$ was characterized by low concentration level, and $43 \%(n=37)$ high concentration level. Figure 1 demonstrates the changes of IGF-I concentration of the two groups throughout the rearing period. The two lines approach each other only at $4^{\text {th }}$ months ( 1 group $30.08 \mathrm{mg} / \mathrm{ml}$ and $2^{\text {nd }}$ group 30.85) otherwise they keep a parallel distance over the time.

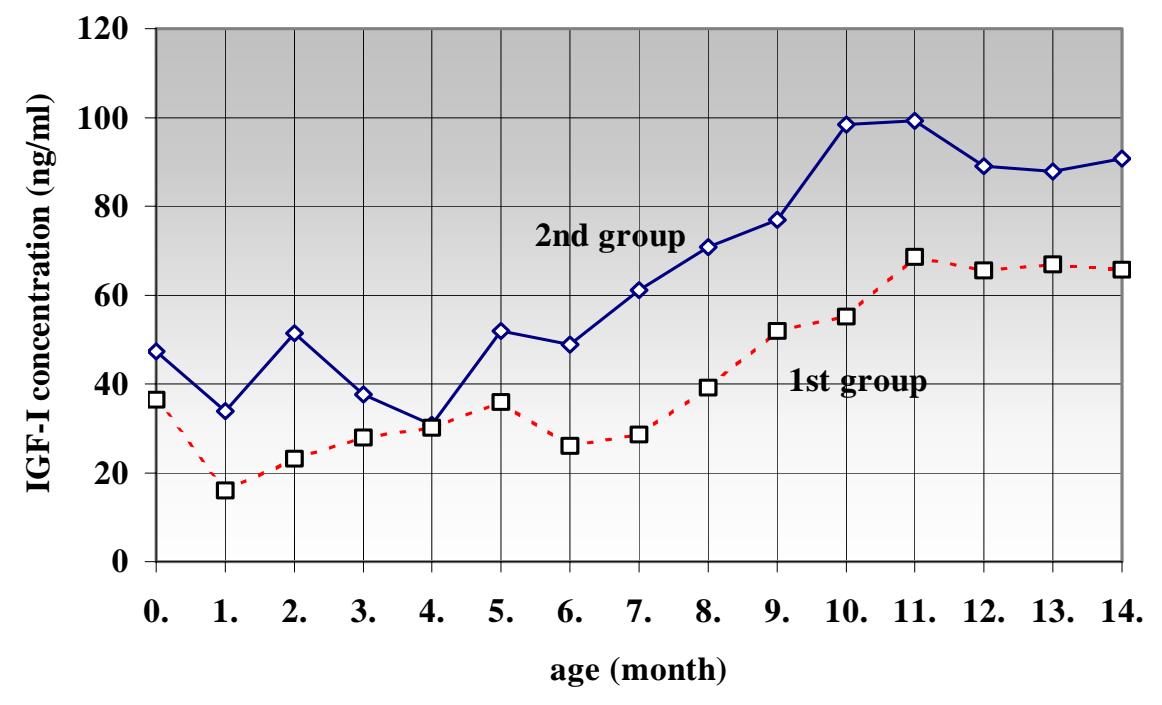

Fig. 1: Change of plasma IGF-I concentration in the $1^{\text {st }}$ and $2^{\text {nd }}$ group from birth until the14 $4^{\text {th }}$ month of age (Veränderung der Plasma IGF-I Konzentration in der Gruppe 1 und 2 von Geburt bis zum 14. Lebensmonat)

Five paternal half-sib groups were compared by analysis of variance. The aim at this point was to get explanation for the differences or similarities in plasma IGF-I concentration within and among groups for the rearing period. Results of analysis of 
variance (Table 3) reveal that, bulls have special effect on IGF-I concentrations at birth; $5^{\text {th }} ; 13^{\text {th }}$ and $14^{\text {th }}$ months of age $(\mathrm{P}<0.05)$.

Table 3

Appearence of paternal effect on IGF-I c.c. (Nachweis des Vatereffektes auf die IGF-I Konzentration)

\begin{tabular}{ccccc}
\hline Age & MQ & Error of MQ & F(df1,2) 5,68 & Szign. level \\
\hline $\mathbf{0}$ & 132.04 & 52.89 & 2.496 & $\mathbf{0 . 0 3 9}$ \\
$\mathbf{1}$ & 399.35 & 454.01 & 0.879 & 0.499 \\
$\mathbf{2}$ & 955.80 & 1308.28 & 0.730 & 0.602 \\
$\mathbf{3}$ & 615.77 & 859.76 & 0.716 & 0.613 \\
$\mathbf{4}$ & 673.10 & 439.10 & 1.532 & 0.191 \\
$\mathbf{5}$ & 2351.37 & 876.40 & 2.682 & $\mathbf{0 . 0 2 8}$ \\
$\mathbf{6}$ & 1189.95 & 596.88 & 1.993 & 0.090 \\
$\mathbf{7}$ & 658.10 & 992.20 & 0.663 & 0.652 \\
$\mathbf{8}$ & 1240.77 & 911.28 & 1.361 & 0.249 \\
$\mathbf{9}$ & 1128.73 & 796.24 & 1.417 & 0.229 \\
$\mathbf{1 0}$ & 1160.77 & 1232.74 & 0.941 & 0.459 \\
$\mathbf{1 1}$ & 948.82 & 1137.26 & 0.834 & 0.529 \\
$\mathbf{1 2}$ & 643.56 & 643.77 & 0.999 & 0.424 \\
$\mathbf{1 3}$ & 1107.68 & 511.49 & 2.165 & $\mathbf{0 . 0 4 8}$ \\
$\mathbf{1 4}$ & 1516.08 & 680.58 & 2.227 & $\mathbf{0 . 0 5 1}$ \\
\hline
\end{tabular}

Means with different superscripts differ $(\mathrm{p}<0.05)$

Changes of IGF-I concentration, age and body weight follow similar and increasing tendency during the rearing period. Changes of IGF-I concentration and body weight were correlated during the rearing period. BREIER et al. (1988c) found close positive correlation between birth weight and IGF-I concentration of calves. On the contrary, in our trial negative correlation $(\mathrm{r}=-0.31 ; \mathrm{P}<0.05)$ was found between IGF-I and birth weight for the entire population, while positive and negative relations may occur between the two traits within single progeny groups. The relation has minus sign in case of bulls Bellton $(r=-0.34)$, Lincoln $(r=-0.36)$, Showboy $(r=-30)$ and Stardow $(r$ $=-0.11)$ but it is positive for the progenies of Legacy bull $(\mathrm{r}=0.50)$, the single one coinciding with the reference in the literature.

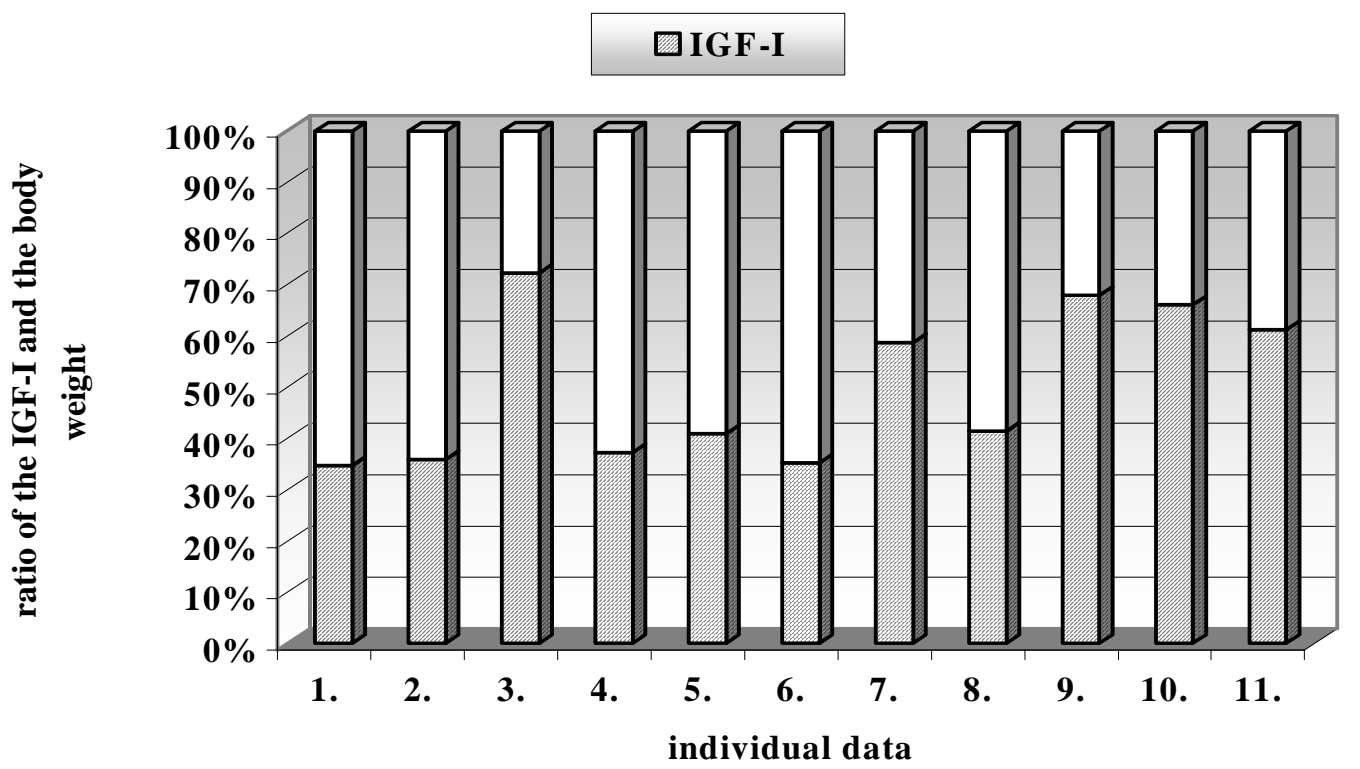

Fig. 2.: Ratio of the IGF-I c.c. and the body weight at the birth in the progeny of Bellton bull (Zusammenhang zwischen der IGF-I Konzentration und dem Körpergewicht bei Geburt von Nachkommen des Bullen Bellton) 
Explanation for this occurrence two possible interpretations may arise on the basis of the trait relations within the paternal progeny groups. The first one is as follows: in three paternal half-sib groups high birth-weight is bound with low IGF-I level and inversely, low weight with high IGF-I. This is demonstrated by the example of bull Bellton in Figure 2. Thus, smaller calves should have higher hormone level to their more intensive growth at the start of life. The second: in the group of Stardow bull all the calves have high birth-weight (over population average), therefore their IGF-I level is consequently low (Fig. 3). Evidence of compensation ability might be due to high IGF-I concentration in calves of low birth weight._Positive relation may only occur if calves are born with weight near the average by narrow standard deviation.

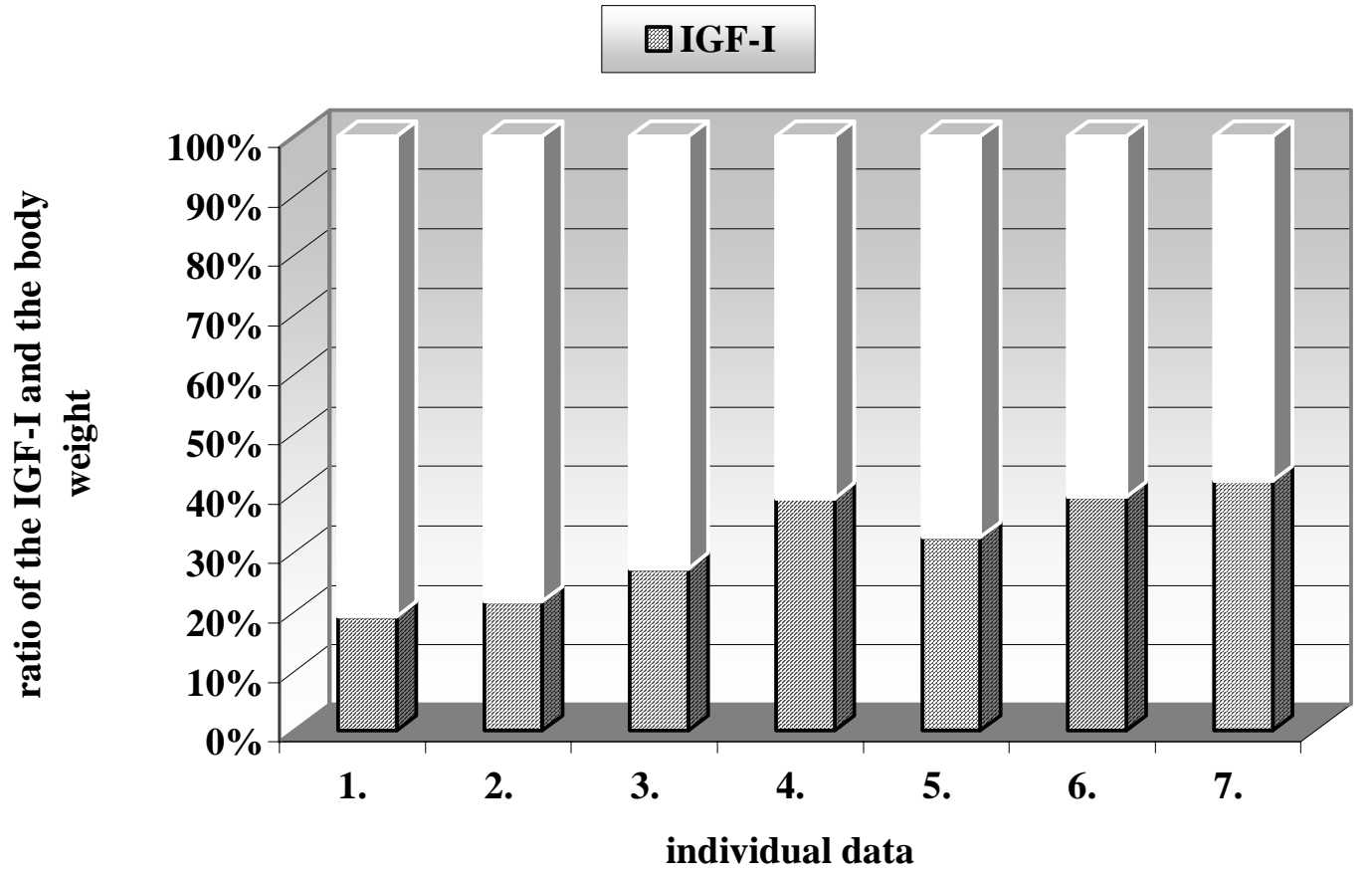

Fig. 3.: Ratio of the IGF-I c.c. and the body weight at the birth in the progeny of Stardow bull (Zusammenhang zwischen der IGF-I Konzentration und dem Körpergewicht bei Geburt von Nachkommen des Bullen Stardow)

The analysis of relation between body weight and IGF-I concentration revealed that the subpopulation 1 with IGF-I level under the population average has monthly weights below the average, as well. The subpopulation 2 having IGF-I level over the average has higher body weight over the population average, too.

On basis of this occurrence, when animals are assorted according to their IGF-I concentration being over or beyond the population average, then their growth rate has to adjust itself to these levels. On this way, individuals of a population may be categorised into slowly or intensively growing groups. To prove this assumption growing intensity of the calves was related to the population average and two groups were established. In subpopulation 1 monthly weight of calves was lower and IGF-I level was higher than general average and it was in inverse ratio in the subpopulation 2. This means animals having IGF-I level under the population average, show lower growth rate and inversely. 


\section{Discussion}

According to the determination of hormone concentration the IGF-I profile can be described for the rearing period in Holstein-Friesian heifers. On basis of results, plasma IGF-I concentration and life time are in straight ratio.

From data above, it can be concluded that in case of high IGF-I hormone concentrations at birth the same values are higher at the $1^{\text {st }}$ and $13^{\text {th }}$ months, as well and inversely. At the same time high IGF-I concentration at birth is bound with low level of it at the $4^{\text {th }}$ and $12^{\text {th }}$ month value and inversely. Birth IGF I hormone concentration has no further significant effect during the rearing period. Comparing hormone levels at the time of sexual maturity supposed, one can state that IGF-I concentration at $5^{\text {th }}$ life month is in intermediate and positive relation with the value at $4^{\text {th }}(b=0.581)$ and $10^{\text {th }}$ month $(b=0.241)$ of age. The $5^{\text {th }}$ month concentration has no further statistically proved relations. Results allow the conclusion that, when in $2^{\text {nd }}$ life month calves show high hormone concentrations then high concentrations can be expected between 6-8 months but low values at the $13^{\text {th }}$ month. IGF-I concentration characteristic for the $11^{\text {th }}$ month show low coefficients of correlation with that of the $8^{\text {th }}(b=0.262)$ and $12^{\text {th }}(b=0.282)$ months. Between the $12^{\text {th }}$ and $11^{\text {th }}(b=0.262)$ middle relation have been found for IGF-I.

BLAIR et al. (1987) and SCHAMS et al.(1988) found higher IGF-I c.c. in bulls than in heifers. It is in accordance with the higher growth rate of bulls. Comparing our results with theirs it can be observed that the maximal value of the IGF-I concentration is at the $9^{\text {th }}$ month of the bulls, which is 3 month earlier than in the heifers. That means a sexual dimorphism.

All these results suggest that IGF-I hormone has a great influence on growth intensity during the rearing period.

Compared groups 1 and group 2 the result allow the statement that IGF-I profile, in spite of large standard deviation, is identical for each individual and calves can be qualified according to their IGF-I value over or below the population average.

The relation described between IGF-I level and monthly body weight in the two subpopulations is the same as NEDBAL et al. (2000) found in mice selected for body weight over more than 50 generations.

\section{Conclusions}

1. Analysis of plasma IGF-I c.c. of individuals indicates that calves with similar IGF-I profile may have low or high hormone concentration during rearing which is an inherited property.

2. IGF-I level (low-high) affects growing intensity. Calves with high IGF-I concentration grow faster and achieve larger body weight at $14^{\text {th }}$ month of age.

3. Live weight and IGF-I concentration at birth is in negative correlation. For this reason, calves with low weight are able to compensate (partly) the lack of weight by their higher IGF-I level.

\section{References}

BASERGA, R.; PRISCO, M.; HONGO, A.:

IGFs and cell growth. In: The IGF System. Eds. ROSENFELD R.G. and ROBERTS JR. C.T. TOTOWA. N.J.: Humana Press. Inc., (1999), 329-353

BAUMRUCKER, C.R.; STEMBERGER, B.H.: 
Insulin and insulin-like growth factor I stimulate DNA synthesis in bovine mammary tissue in vitro. J. Anim. Sci. 67 (1989), 3503-3514

BLAIR, H.T.; McCUTCHEON, S.; MACKENZIE, D.; GLUCKMAN, P.D.; ORMSBY, J.E.:

Variation in plasma concentration of insulin-like growth factor-I and its covariation with live weight in mice. Aust. J. Biol. Sci. 40 (1987), 287-293

BREIER, B.H.; GLUCKMAN, P.D.; BASS, J.J.:

Plasma concentrations of insulin-like growth factor-I and insulin in the infant calf: ontogeny and influence of altered nutrition. J. Endocrinol. 119 (1988), 43-50

FROESCH, E.R.; SCHMID, C.; ZANGGER, I.; SCHOENLE, E.; EIGENMANN, E.; ZAPF, J.:

Effects of IGF/somatomedins on growth and differentiation of muscle and bone. J. Anim. Sci. 63 ((1986) suppl. 2), 57-63

GREEN, H.; MORIKAWA, M.; NIXON, T.:-

A dual effector theory of growth hormone action. Differentiation. 29 (1985), 195-208

LEMAL, D.; RENAVILLE, R.; CLAES, V.; RUELLE, L.; FABRY, J.; BURNY, A.; UNDERWOOD, L.E.;

KETELSLEGERS, J.-M.:

Effect of pituitary somatotropin injections on plasma insulin-like growth factor I and somatotropin profiles in growing heifers. J. Anim. Sci. 67 (1989), 2715-2723

NEDBAL, S.; ZINK, N.; LAHM, H.; HOEFLICH, A.; WOLF. E.:

Functional dissection of the insulin-like growth factor (IGF) system-prospects for animal breeding. Arch. Tierz., Dummerstorf 43 (2000) 3, 223-230

RINDERKNECHT, E.; HUMBEL, R.E.:

Primary structure of human insulin-like growth factor II. FEBS Lett. 89 (1978a), 283-286

RINDERKNECHT, E.; HUMBEL, R.E.:

The amino acid sequence of human insulin-like growth factor I and its structural homology with proinsulin. J. Biol. Chem. 253 (1978b), 2769-2776

SCHAMS, D.; WINKLER, U.; SCHALLENBERGER, E.; KARG, H.:

Wachstumshormon und insulin-like growth factor I (Somatomedin-C)-Blutspiegel bei Rindem von der Geburt bis nach der Pubertät. Dtsch. tierärztl. Wschr. 95 (1988), 360-362

SCHMIDT, C. STEINER, T.; FROESCH, E.R.:

Preferential enhancement of myoblast differentiation by insulin-like growth factors (IGF-I and IGF-II) in primary cultures of chicken embryonic cell. F.E.B.S. Letters. 161 (1983), 117-121

SCHLECHTER, N.L.; RUSSEL, S.M.; SPENCER, E.M.; NICOLL, C.S.:

Evidence to suggest that the direct growth promotin effects of growth hormone on cartilage in vivo are mediated by local production of somatomedin. Proc. Natl. Acad. Sci. 83 (1986), 7932-7934

SHAMAY, A.; COHEN, N.; NIWA, M.; GERTLER, A.:

Effect of insulin-like growth factor I on deoxyribonucleic acid synthesis and galactopoiesis in bovine undifferentiated and lactating mammary tissue in vitro. Endocrinol. 123 (1988), 804-809

SOARES, M.B.; ISHII, D.N.; EFSTRATIADIS, A.:

Developmental and tissue-specific expression of a family of transcripts related to rat insulin-like growth factor II mRNA, Nucleic Acids Res. 13 (1985), 1119-1134

UNDERWOOD, L.E.; D'ERCOLE, A.J.; CLEMMONS, D.R.; VAN WYK, J.J.:

Paracrine functions of somatomedin. Clinics in Endocrinology and Metabolism paracrine control. 15 (1986), 59-77. Editor Franchimont. London

ZAPF, J., SCHOENLE, E.; FROESCH, E.:

Insulin-like growth factors I and II: some biological actions and receptor binding characteristics of two purified constituent of non suppressible insulin-like activity of human serum. Eur. J. Biochem. 87 (1978a), 285-296

ZAPF, J., RINDERKNECHT, E., HUMBEL, R.; FROESCH, E.:

Nonsuppressible insulin-like activity (NSILA) from human serum: recent accomplishments and their physiologic implications. Metabolism. 27 (1978b), 1803-1828

Received: 2002-09-19

Accepted: 2002-11-21

Author's address

MÁRIA HORVAI SZABÓ, Szent István University

School of Agricultural and Environmental Sciences

Animal Husbandry Department

2103-Gödöllő, Páter Károly u. 1.

Hungary

E-Mail: $\underline{\text { Horvaine@fau.gau.hu }}$ 